\title{
ANALISIS PENGARUH RIBA TERHADAP TINGKAT KEMACETAN DI IBU KOTA JAKARTA
}

\author{
Ruslan Husen Marasabessy ${ }^{1}$ \\ rully.ief@gmail.com
}

\begin{abstract}
The first and foremost reason riba is haram is because Allah declared it so. It is based on Allah's infinite wisdom that He deems an action to be obligatory or prohibited, prescribing matters in man's best interests, in this life and in the Hereafter, as He is the All-Wise, AllKnowing. The scholars of Islam have suggested the following reasons as to why riba is haram:There are many proofs showing that riba is haram and one of the most serious sins in Islam.Abu Hurayra said, the Messenger of Allah (pbuh) said: A time will come over mankind when not a single person will remain who does not consume riba (usury, interest); and if one does not consume it, the vapor or dust of it will reach him.nowdays Living in a capitalist society makes it difficult to completely avoid riba.however, the threat is not enough for the community to avoid the usury case. the effect of usury in real terms must be clearly described, in order to raise public awareness. the consumption behavior of motor vehicles is one of the causes of congestion in urban areas, many people use usury (Leasing) to buy vehicles, There are many reasons why we suffer traffic jams every day. One of these is the rapid growth of the population. As a result of this, the number of cars is increasing annually. Jakarta was named the world city with the worst traffic in one index last year. An estimated 70\% of the city's air pollution comes from vehicles. this paper found that congestion in Jakarta is caused by usury, this can be seen from the high use of usury instruments in motor vehicle financing (leasing)
\end{abstract}

keyword : riba, usury, financing, leasing, consumer behavior

\section{A. Pendahuluan}

Masalah umum yang dihadapi oleh negara-negara berkembang adalah tingkat pertumbuhan penduduk yang tinggi, produksi dan standar hidup yang rendah, ketergantungan terhadap barang-barang eksport dan tingginya tingkat kemiskinan masih merupakan momok yang belum dapat diselesaikan secara tuntas. Indonesia sebagai salah satu dari negara berkembang dengan populasi pertumbuhan penduduk yang sangat tinggi justru telah memberikan dampak negatif baru terhadap padatnya arus lalu lintas di jalanan ibu kota.

\footnotetext{
${ }^{1}$ Dosen Tetap Prodi Muamalah STAI Asy-Syukriyyah
} 


\section{Jurnal Asy-Syukriyyah}

Jakarta adalah representasi sebuah kota megapolitan di republik ini dengan siklus perekonomian yang berjalan sangat cepat telah menjadi daya tarik tersendiri bagi masyarakat Indonesia di provinsi lainnya untuk datang, tinggal dan bekerja di ibu kota Jakarta. Daya tarik ini membentuk sebuah pola urbanisasi di ibu kota Jakarta yang berefek pada pertumbuhan populasi penduduk yang tidak dapat dikontrol oleh pemerintah Jakarta. Provinsi DKI Jakarta memiliki luas wilayah 662,33 km2 (SK Gubernur No.171/2007) terbagi menjadi 5 kota administrasi dan 1 kabupaten administrasi, yang meliputi 44 kecamatan dan 267 kelurahan. Berdasarkan data dari Dinas Kependudukan dan Catatan Sipil dan Biro Tata Pemerintahan tahun 2014 tercatat sebanyak 2.726 Rukun Warga (RW) dan 30.536 Rukun Tetangga (RT). Jumlah penduduk DKI Jakarta tahun 2015 (proyeksi) sebanyak 10.177,9 ribu orang. Survei Komputer 2014, Penduduk malam hari di DKI Jakarta sebesar 10.075.310 orang sedangkan penduduk DKI Jakarta siang hari sebesar 11.201.620 orang ${ }^{2}$.

Populasi yang tinggi tersebut berakibat kepada padatnya arus lalu lintas di jalanan. Lalu lintas kota Jakarta yang macet menjadi sebuah permasalahan klasik di ibu kota Jakarta. Berdasarkan UU no 2 tahun 1999 mendefinisikan lalu lintas sebagai gerak kendaraan dan orang di ruang lalu lintas jalan, sedangkan yang dimaksud dengan ruang lalu lintas jalan adalah prasarana yang diperuntukkan bagi gerak pindah kendaraan, orang dan atau barang yang berupa jalan dan fasilitas pendukung, akan tetapi hingga saat ini pemerintah belum berhasil untuk menyelesaikan permasalahan ini. Kota Jakarta memiliki luas wilayah yang statis, hal ini tentunya membuat pemerintah kesulitan untuk memperluas area jalan umum untuk mengurangi kemacetan, karena masyarakat juga membutuhkan ruang yang lebih untuk hunian dan tempat tinggal.

Keterbatasan ini pada akhirnya membuat kemacetan semakin parah di ibu kota Jakarta. Untuk mengatasi hal tersebut maka pemerintah harus meningkatkan fasilitas umum atau transportasi public untuk mengurangi kendaraan pribadi di jalanan, busway, Commuter line, monorail, yang telah diadopsi oleh pemerintah untuk mengurangi kemacetan di ibu kota Jakarta. Ironisnya, pertambahan transportasi public justru semakin memperparah kemacetan di ibu kota Jakarta. Hal ini lebih dikeruhkan lagi dengan kesadaran berlalu lintas yang sangat rendah di kalangan masyarakat ibu kota dengan

\footnotetext{
${ }^{2}$ Informasi Statistik BPS Jakarta April 2016
} 


\section{Jurnal Asy-Syukriyyah}

perilaku tidak mentaati lampu merah, parkir liar, menerobos fasilitas umum seperti trotoar telah menjadi hal yang lumrah di jalanan ibu kota. Penegakkan hukum yang telah diterapkan oleh pemerintah untuk mengurangi kemacetan juga tidak begitu signifikan dalam pengimplementasiannya. Penetapan aturan three in one pada akhirnya memunculkan joki three in one, penerapan ERP membuat masyarakat mencari jalan lain untuk mengakali hukum. Kesadaran dan pola masyarakat itu sendiri tidak sejalan dengan penegakkan hukum yang lagi-lagi selalu memunculkan sebuah permasalahan baru.

Kemacetan ini tentunya berefek negatif kepada perekonomian, psikologis dan psiologis bagi para pengendara. Dari segi ekonomi, kemacetan lalu lintas di Jakarta telah menyebabkan kerugian Rp. 43 triliun per tahun, menurut pengamat politik dari Universitas Indonesia (UI), Andrinof Chaniago ${ }^{3}$. Setiap tahun nilai kerugian masyarakat mencapai Rp. 43 triliun per tahun oleh belanja boros akibat kemacetan. Pengeluaran tambahan yang dibebankan warga akibat kemacetan yakni belanja onderdil yang meningkat, pembelian Bahan Bakar Minyak (BBM) serta timbulnya penyakit fisik dan psikis. Bahkan angka yang lebih tinggi meningkat pada tahun 2015 sebagaimana dikemukakan oleh Kepala Badan Penelitian dan Pengembangan Kementerian Pekerjaan Umum dan Perumahan Rakyat, Arie Setiadi Moerwanto ${ }^{4}$, bahwa tingkat kerugian mencapai angka 63 trilyun. Biaya produksi yang meningkat seiring dengan pemborosan bahan bakar yang terbuang akibat kemacetan yang ditimbulkan. Biaya produksi yang tinggi juga membuat investor akan sangat berhatihati untuk berinvestasi di Indonesia, khususnya di ibu kota Jakarta.

Secara psikologis, dampak yang ditimbulkan oleh kemacetan juga sangat memprihatinkan. Kemacetan membentuk watak masyarakat Jakarta menjadi lebih keras, tidak sabar, dan egoisme yang meningkat. Hal ini berimplikasi pada produktifitas kerja yang menurun. Kemacetan juga membentuk emosional yang negatif pada setiap pengendara di ibu kota Jakarta, tidak jarang keadaan psikologis ini terbawa di dalam keluarga ketika pengendara sudah kembali ke rumah, dan tidak jarang ketidakharmonisan rumah tangga seseorang diakibatkan oleh tingkat kemacetan yang sangat tinggi.

Secara kesehatan, kemacetan membuat para pengendara di ibu kota Jakarta akan terlambat untuk tiba di rumah,dan hal ini membuat kualitas tidur seorang pengendara akan sangat berkurang karena harus bangun pagi untuk berangkat ke kantor untuk menghindari

\footnotetext{
${ }^{3}$ Wawancara kantor berita AntaraNews

${ }^{4}$ Dimuat di koran Republika tahun 2015 tanggal 22 mei
} 
kemacetan. Gallup-Healthways Well-Being Index melakukan survei dan menemukan bahwasanya seorang pengendara yang berkendara lebih dari 3 jam per hari akan mengalami gejala kegelisahan yang berlebihan, hal ini disebabkan kecemasan akan keterlambatan untuk tiba di kantor. Nyeri sendi juga merupakan akibat yang muncul akibat terlalu lamanya seseorang berkendara. Akibat yang lebih global adalah polusi yang diciptakan oleh kemacetan, tingkat $\mathrm{CO} 2$ yang ditimbulkan oleh asap kendaraan sangat berbahaya bagi masyarakat sekitar, terlebih lagi kepada seorang bayi. Heather Volk dari USC Keck School of Medicine menemukan bahwa ibu-ibu yang tinggal 1.000 kaki dari jalan raya di Los Angeles, San Francisco, dan Sacramento kemungkinan besar akan melahirkan anak dengan gangguan autisme. Sebuah penelitian jangka panjang yang dikembangkan oleh Frederica Perera dari Columbia University's Center for Children's Enviromental Health menunjukkan adanya pengaruh buruk dari emisi CO2 terhadap kandungan. Perkembangan kapasitas mental yang lambat, tingkat IQ yang lebih rendah, serta tingkat kecemasan, depresi, dan kesulitan konsentrasi merupakan sebagian dari efek samping yang dihasilkan.

Dari berbagai macam variabel penyebab kemacetan di atas, penulis menyimpulkan bahwa penyebab kemacetan di ibu kota Jakarta lebih dikarenakan oleh pertumbuhan kendaraan yang sangat tinggi. Pertumbuhan jumlah kendaraan di ibu kota Jakarta tidak pernah turun, bahkan selalu meningkat setiap tahun, hal ini berbanding terbalik dengan pertumbuhan jalan ibu kota yang minim bahkan cenderung statis. Menurut kepala Bidang Hubungan Masyarakat Polda Metro Jaya, Komisaris Besar Polisi Martinus ketika di wawancara Antaranews mengatakan bahwa Kendaraan bermotor di Jakarta dan sekitarnya naik 12 persen per tahun. Berdasarkan data yang dikeluarkan oleh Direktorat Lalu Lintas Polda Metro Jaya, jumlah kendaraan bermotor di Jakarta dan sekitarnya bertambah sebanyak 5.500 hingga 6.000 unit kendaraan per hari. Jumlah tersebut didominasi oleh pertambahan sepeda motor yang mencapai 4.000 hingga 4.500 per hari. Sedangkan kendaraan roda empat mengalami pertumbuhan sebanyak 1.600 unit per hari. Jumlah tersebut, kata Martinus, berdasarkan Surat Tanda Nomor Kendaraan (STNK) yang dikeluarkan Samsat Polda Metro Jaya setiap harinya ${ }^{5}$.

\footnotetext{
${ }^{5}$ Di muat di Antaranews http://www.antaranews.com/berita/473169/jumlah-motor-dan-mobil-di-jakartatumbuh-12-persen-tiap-tahun
} 


\section{Jurnal Asy-Syukriyyah}

Salah satu solusi pemerintah untuk mengurangi kemacetan adalah dengan mengurangi produksi kendaraan bermotor. Tentunya ini adalah sebuah dilematis bagi pemerintah republik ini yang tersandera oleh syarat kerjasama otomotif dengan negara penghasil otomotif terbesar di dunia yaitu Jepang. Jepang adalah negara kreditur terbesar bagi Indonesia, tercatat pada tahun 2015 utang republik ini terhadap jepang mencapai 226,02 trilyun $^{6}$. Implikasi dari hutang ini membuat negara kita harus melakukan kerjasama otomotif dengan negara jepang, dan ini membuat negara kita tidak bisa mandiri untuk mengembangkan industry otomotif dalam negeri, secara makro, penulis berasumsi bahwa ketergantungan hutang yang menimbulkan syarat kerja sama ini adalah pinjaman hutang luar negeri yang dikategorikan sebagai tied loan dan mengandung unsur ribawi yang sangat tinggi. Oleh sebab itu, penulis ingin meneliti lebih dalam implikasi ribawi terhadap tingkat kemacetan di Jakarta.

Sebagian besar masyarakat di ibu kota Jakarta adalah masyarakat modern yang tingkat kebutuhannya akan kendaraan sangat tinggi. Hal ini dilakukan untuk mendukung mobilitas masyarakat urban yang sangat cepat di perkotaan. Ironisnya, mayoritas masyarakat Jakarta tidak memahami akan bahaya riba, dan ketidaktahuan masyarakat membuat mereka tenggelam di dalam praktik riba. Keinginan untuk memiliki kendaraan pribadi membuat masyarakat mencari lembaga dan institusi ribawi dalam memenuhi kebutuhan mereka akan kendaraan bermotor tanpa memperhatikan atau mempedulikan asal muasal harta yang diperoleh.

Rasulullah saw bersabda:

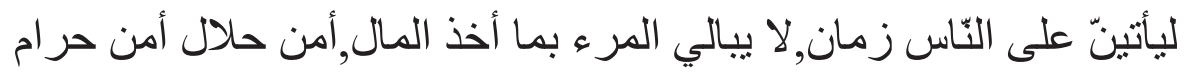

"Akan datang suatu masa, dimana orang tidak lagi mempedulikan darimana harta yang dihasilkannya, apakah dari jalan yang halal atau dari jalan yang haram”.(HR.Bukhari)

Berdasarkan hadits ini, maka golongan masyarakat bisa dikategorikan mejadi dua bagian berdasarkan cara-cara mendapatkan harta di dalam bermuamalah, yakni;

a) Golongan yang tidak memperhatikan syariat Allah swt di dalam memenuhi kebutuhan hidupnya dan cenderung melanggar kaidah Rabbani.,

\footnotetext{
${ }^{6}$ Direktorat Pengelolaan Pembiayaan dan Resiko Kemenkeu
} 
b) Golongan yang memiliki kebaikan di dalam hati mereka, akan tetapi ketidaktahuan akan syariat membuat mereka melanggar perintah Allah di dalam mengumpulkan harta. Sebagaimana yang dinukil oleh Abu layts (tanbih Al Ghafilin,Hal 364)

$$
\text { من اتُجر قبل أن يتفقه في الدّين,فقدر تطم في الرّبا ثمّ ارتطم ثمّ ارتطم }
$$

"Barangsiapa yang melakukan perniagaan sebelum mempelajari fikih (muamalat) dia akan terjerumus ke dalam riba, dia akan terjerumus dan terjerumus"

Banyaknya institusi-institusi riba di Indonesia khususnya di ibu kota Jakarta telah memberikan kemudahan kepada para pekerja dan karyawan serta masyarakat untuk memiliki kendaraan dengan cara yang instan dan cepat. Leasing memberikan angin segar kepada masyarakat yang tidak dapat membeli kendaraan secara tunai. Hal ini menyebabkan menjamurnya perusahaan leasing atau lembaga pembiayaan. Bank atau leasing akan melakukan pembiayaan terlebih dahulu kepada nasabah yang ingin melakukan pembelian kendaraan bermotor yang disyaratkannya Down payment $30 \%$ kepada masyarakat dengan dana yang tidak terlalu besar. Kajian riset infobank menemukan bahwa terdapat 173 perusahaan leasing dan multifinance di Indonesia.

Berdasarkan data multifinance dan leasing dari infobank $2015^{7}$ Rating 173 Multifinance versi Infobank 2015. Untuk kategori perusahaan pembiayaan beraset Rp10 triliun ke atas:

1) Summit Oto Finance,

2) Federal International Finance,

3) Oto Multiartha,

4) Astra Sedaya Finance,

5) Central Java Finance,

6) Toyota Astra Financial Services, dan

7) Dipo Star Finance.

Untuk kelompok perusahaan pembiayaan beraset Rp. 5 triliun sampai dengan di bawah Rp10 triliun :

1) Clipan Finance Indonesia,

2) BFI Finance Indonesia,

3) BCA Finance,

\footnotetext{
${ }^{7}$ Infobank 2015
} 


\section{Jurnal Asy-Syukriyyah}

4) Mitra Pinasthika Mustika Finance,

5) Orix Indonesia Finance,

6) Indomobil Finance Indonesia,

7) Mandiri Tunas Finance,

8) Surya Artha Nusantara Finance, dan

9) Mitsui Leasing Capital Indonesia.

Kelompok perusahaan pembiayaan beraset Rp. 1 triliun sampai dengan di bawah Rp. 5 triliun cukup banyak, di antaranya adalah :

1) Mandala Multifinance,

2) Nusa Surya Ciptadana,

3) Karya Technik Multifinance,

4) Equity Finance Indonesia,

5) Century Tokyo Leasing Indonesia,

6) BII Finance Center,

7) Batavia Prosperindo Finance,

8) Intan Baruprana,

9) Mega Central Finance,

10) Bentara Sinergies Multifinance.

Adapun kategori perusahaan pembiayaan beraset Rp. 500 miliar sampai dengan di bawah Rp. 1 triliun;

1) Mega Auto Finance,

2) Ciptadana Multifinance,

3) Swadharma Bhakti Sedaya Finance,

4) Bintang Mandiri Finance,

5) Astra Multifinance,

6) Bima Multi Finance,

7) Reksa Finance,

8) Bringin Srikandi Finance,

9) Swadharma Indotama Finance, dan

10) Dana Unico Finance. 
Mayoritas perusahaan multifinance berada pada kategori perusahaan beraset $\mathrm{Rp}$. 100 miliar sampai dengan di bawah Rp. 500 miliar:

1) Mega Finance,

2) Paramita Multifinance,

3) AB Sinar Mas Multifinance,

4) Danareksa Finance,

5) Karunia Multifinance,

6) Usaha Pembiayaan Reliance Indonesia,

7) PPA Finance,

8) Danpac Finance,

9) Otomas Multifinance, dan

10) Arjuna Finance.

Di kelas terbawah adalah kategori perusahaan pembiayaan beraset di bawah Rp.100 miliar:

1) Panen Arta Indonesia Multifinance,

2) Pratama Sedaya Finance,

3) Murni Upaya Raya Nilai Inti Finance,

4) Daindo Internasional Finance,

5) Topas MultiFinance,

6) Danasupra Erapacific,

7) Garishindo Buana Finance Indonesia,

8) Adhika Primadhana Multifinance,

9) Rama MultiFinance, dan

10) Fortuna Multifinance.

Data di atas menunjukkan banyaknya institusi ribawi yang digunakan oleh masyarakat di dalam memenuhi pola konsumsi akan kendaraan bermotor, padahal mereka tahu bahwasanya lembaga-lembaga tersebut sarat dengan praktek ribawi yang mendatangkan Adzab Allah swt. Penulis berasumsi bahwa kemacetan adalah salah satu bentuk adzab Allah swt kepada masyarakat yang tenggelam di dalam praktek riba di ibu kota Jakarta. Dengan kata lain, sistematis praktek ribawi di ibu kota Jakarta berdampak 
negatif terhadap kemacetan dan juga berimplikasi kepada perekonomian, kesehatan, lingkungan dan psikologis.

Untuk itulah, penulis tertarik untuk meneliti lebih mendalam sejauh mana "Signifikansi Leasing Konvensional dan Leasing Syariah terhadap kemacetan dalam Perspektif TSR". Mengingat variable riba ini jarang sekali diangkat di dalam analisisanalisis penyebab kemacetan di ibu kota Jakarta dan juga desertasi ini adalah sebuah penegasan kepada masyarakat akan pengaruh riba yang sangat sistematis terhadap kehidupan sosial masyarakat di Indonesia khususnya di ibu kota Jakarta.

Berdasarkan latar belakang di atas, peneliti merumuskan masalah penelitian ini sebagai berikut:

a. Seberapa besarkah signifikansi tingkat pengetahuan masyarakat tentang riba terhadap kemacetan di ibu kota Jakarta?

b. Seberapa besarkah signifikansi daya beli masyarakat terhadap kemacetan di ibu kota Jakarta?

c. Seberapa besarkah signifikansi indeks pendapatan masyarakat terhadap kemacetan di ibu kota Jakarta?

d. Seberapa besarkah signifikansi tingkat pengetahuan masyarakat tentang riba terhadap kemacetan melalui perilaku masyarakat?

e. Seberapa besarkah signifikansi daya beli masyarakat terhadap kemacetan di ibu kota Jakarta melalui perilaku masyarakat?

f. Seberapa besarkah signifikansi indeks pendapatan terhadap kemacetan melalui perilaku masyarakat?

\section{B. Kajian Teori}

\section{Definisi Leasing}

Sewa guna usaha (leasing) pada awalnya di kenal di Amerika Serikat, yaitu berasal dari kata lease yang berarti menyewa. Sedangkan dalam ekonomi Islam istilah yang berkaitan dengan leasing adalah Ijarah(al-ijarah) yang berasal dari kata al-ajru yang berarti al-'iwadhu (ganti). Untuk memahami lebih lanjut, berikut ini akan dikemukakan definisi dari penjelasannya. 
Berdasarkan SK Menteri Keuangan No.1169/KMK.01/1991 tanggal 21 November 1991, sewa guna usaha adalah kegiatan pembiayaan dalam bentuk penyediaan barang modal baik secara sewa guna usaha dengan menggunakan hak opsi (finance lease) maupun sewa guna usaha tanpa hak opsi (operating lease) untuk digunakan oleh lessee selama jangka waktu tertentu berdasarkan pembayaran secara berkala ${ }^{8}$.

Ijarah adalah akad pemindahan hak guna atas barang dan jasa, melalui pembayaran upah sewa, tanpa diikuti dengan pemindahan kepemilikan (ownership/milkiyah) atas barang itu sendiri. Dalam konteks perbankan syariah, ijarah adalah merupakan lease contract dimana suatu bank atau lembaga keuangan menyewakan peralatan (equipment) kepada salah satu nasabahnya berdasar pembebanan biaya yang sudah ditentukan secara pasti sebelumnya (fixed charge). Mekanisme yang dilakukan di sector perbankan syariah adalah sebagai berikut:

a. Transaksi Ijarah ditandai dengan adanya pemindahan manfaat. Jadi dasarnya prinsip Ijarah sama saja dengan jual beli. Namun, perbedaan terletak pada obyek transaksinya, pada Ijarah obyeknya adalah jasa

b. Pada akhir sewa, bank dapat saja menjual barang yang disewakan kepada nasabah. Karena itu dalam perbankan syariah dikenal ijarah Muntahiya Bittamlik (Ijarah dengan wa'ad perpindahan kepemilikan objek ijarah pada saat tertentu).

c. Harga sewa dan harga jual disepakati pada awal perjanjian antara bank dengan nasabah $^{9}$.

d. Leasing Ijarah adalah pengadaan barang modal oleh lessor diikuti perpindahan kepemilikan kepada lessee dengan cara pembelian saham kepemilikan secara angsuran ${ }^{10}$.

Dalam setiap transaksi leasing terdapat 3 (tiga) pihak utama yaitu ${ }^{11}$ :

a. Lessor, merupakan perusahaan sewa guna usaha yang dalam hal ini sebagai pihak yang memiliki hak kepemilikan barang modal.

\footnotetext{
${ }^{8}$ Muhammad, Rifqi. 2008. Akuntansi Keuangan Syariah. Yogyakarta: P3EI Press

${ }^{9}$ Yuliadi, Imamudin. 2007. Ekonomi Islam Filosofi, Teori dan Implementasi. Yogyakarta: LPPI UMY

${ }^{10}$ Sudarsono Heri. 2008. Bank dan Lembaga Keuangan Syariah. Yogyakarta: Ekonisia.

${ }^{11}$ http://www.fifkredit.com/fif/produk-layanan/syariah.php/
} 


\section{Jurnal Asy-Syukriyyah}

b. Lessee, merupakan perusahaan pemakai/penyewa barang modal yang dalam hal ini dapat memiliki opsi/pilihan pada akhir kontrak.

c. Supplier, merupakan pihak penjual barang modal yang disewakan.

d. Asuransi, merupakan perusahaan yang akan menaggung resiko terhadap perjanjian antara lessor dengan lessee. Dalam hal ini lessee dikenakan biaya asuransi dan apabila terjadi sesuatu, maka perusahaan akan menanggung resiko sebesar sesuai dengan perjanjian terhadap barang yang dileasingkan.

\section{Jenis-Jenis Leasing ${ }^{12}$}

\section{Sale and Lease back}

Pada sale and lease back, perusahaan yang memiliki aktiva menjual aktiva tersebut kepada perusahaan lain dan kemudian diikuti perjanjian untuk menyewa kembali aktiva tersebut selama periode tertentu. Aktiva yang digunakan biasanya yaitu: tanah, bangunan, dan peralatan pabrik, sedangkan perusahaan yang biasanya bertindak sebagai pembeli adalah bank, perusahaan leasing, pegadaian, atau investor individu. Manfaat dari sale and lease back ini adalah bahwa lessee menerima pembayaran sebagai tambahan dana yang dapat diinvestasikan ke investasi lain, dan bersamaan dengan itu lessee masih dapat menggunakan aktiva yang dijualnya selama jangka waktu perjanjian leasing. Lesse mempunyai kewajiban membayar secara periodic sebesar harga jual ditambah dengan tingkat keuntungan kepada lessor.

\section{Operating Leases}

Operating leases atau service leases memberikan service baik mengenai bidang keuangan maupun mengenai pemeliharaannya. Jadi pihak lessor menyediakan pendanaan sekaligus biaya perawatan yang keseluruhannya tercakup dalam pembayaran leasing. Aktiva yang sering digunakan adalah computer, mobil, truk, dll. Dalam leasing ini biasanya terdapat klausul yang memberikan hak kepada lesse untuk membatalkan perjanjian leasing dan mengembalikan peralatan itu kepada lessor sebelum habis waktu berlakunya. Hal ini merupakan syarat yang penting bagi lessee, karena ini berarti bahwa lesse dapat mengembalikan peralatan tersebut jika ada perkembangan teknologi baru yang menyebabkan peralatan tersebut menjadi usang.

\footnotetext{
${ }^{12}$ Muhammad, Rifqi. 2008. Akuntansi Keuangan Syariah. Yogyakarta: P3EI Press. Hal.358-360.
} 


\section{Financial Lease}

Financial lease atau capital lease yaitu lessor tidak menanggung biaya perawatan, perjanjian leasing tidak dapat dibatalkan, dan diangsur secara penuh. Dengan demikian lessor menerima pembayaran sebesar harga perolehan aktiva ditambah dengan keuntungan. Pada umumnya juga harus membayar pajak dan asuransi aktiva yang menjadi obyek leasing tersebut. Lessor pada umumnya pihak perusahaan asuransi atau bank komersial.

\section{Riba}

Riba dalam Bahasa arab berarti bertambah, maka segala sesuatu yang bertambah dinamakan riba.menurut istilah riba berarti menambahkan beban kepada pihak yang berhutang (riba dayn) atau menambahkan takaran saat melakukan penukaran 6 komoditi (emas, perak, gandum, sya'ir, kurma dan garam) dengan jenis yang sama atau tukar menukar emas dengan perak dan makanan dengan makanan dengan cara yang tidak tunai (riba $\left.b a^{\prime} i\right)$

\section{Sejarah Riba}

Riba merupakan penyakit ekonomi masyarakat yang telah dikenal lama dalam peradaban manusia. Riba diperkirakan telah ada semenjak manusia mengenal uang, yaitu pada zaman Babilonia, Farao di Mesir, Sumeria dan peradaban Ibrani Yahudi. Termaktub dalam perjanjian lama bahwa diharamkan yahudi mengambil riba dari Yahudi namun dibolehkan orang Yahudi mengambil riba dari orang di luar Yahudi ${ }^{13}$.

Al Quran menjelaskan bahwa bani Israel (Umat Nabi Musa as) melakukan riba dan Allah pun telah melarang mereka memakan riba. Allah swt berfirman:

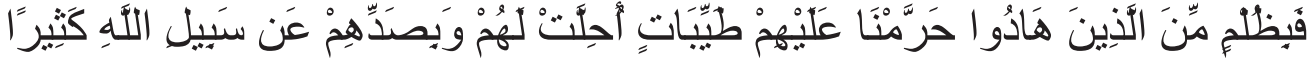

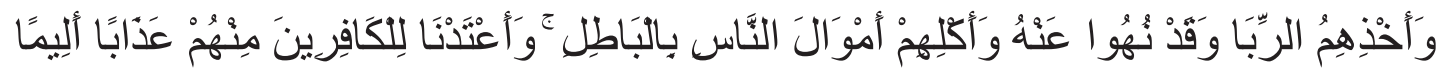

\footnotetext{
${ }^{13}$ Dr Abdullah Al Umrani,Al Manfa'atu fil qardh,hal 186
} 


\section{Jurnal Asy-Syukriyyah}

memakan harta benda orang dengan jalan yang batil, kami telah menyediakan untuk orang-orang yang kafir di antara mereka itu siksa yang pedih" (QS an Nisa 160-161).

Karena adanya hubungan dagang antara bangsa Yahudi dengan bangsa Arab di semenanjung Arabia, tepatnya di kota Thaif dan Yatsrib, maka terjadi asimilasi system ribawi ini antara Yahudi dan bangsa Arab. Praktik ini pada akhirnya menjalar ke Mekkah dan dipraktikkan oleh bangsa Quraisy jahiliyyah ${ }^{14}$. Maka riba marak di kota Mekkah.sebagaimana yang kita ketahui dalam khutbah Rasulullah saw di Arafah pada haji wada', beliau bersabda:

ورباالجاهليّة موضوع,و أوّل ربا أضع ربانا ربا عبّاس بن عبد المطلب,فإنّّه موضو ع كثه

"Riba jahiliyah telah di hapuskan,riba pertama yang kuhapuskan adalah riba Abbas bin Abdul Muthalib, sesungguhnya riba telah dihapuskan seluruhnya" (HR. Muslim).

\section{Hukum Riba}

Hukum haramnya riba adalah sesuatu yang Qath'I dan tidak ada ulama yang berbeda pandangan tentang hal ini, Allah swt berfirman:

$$
\text { و أحلّ الله البيع و حرّم الرّبا }
$$

"Dan Allah menghalalkan jual-beli dan mengharamkankan riba"

Perintah Allah swt kepada orang-orang yang beriman untuk menghentikan praktik riba

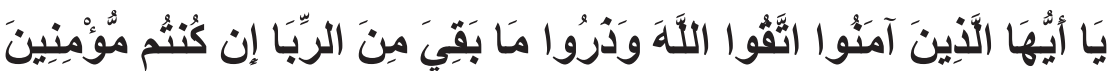

"Hai orang-orang yang beriman, bertakwalah kepada Allah dan tinggalkan sisa riba (yang belum di pungut) jika kamu orang-orang yang beriman”. (Qs Al Baqarah 278).

Dan Allah swt mengancam akan memerangi orang-orang yang tidak menuruti perintah-Nya untuk meninggalkan riba. Firman Allah swt di dalam al qur'an:

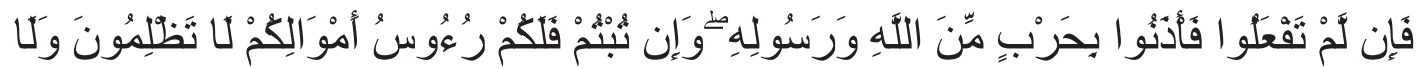

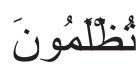

\footnotetext{
${ }^{14}$ Dr Rafiq Al Mishri,Jami’ Ushulurriba,hal 22
} 


\section{Jurnal Asy-Syukriyyah}

"Maka jika kamu tidak mengerjakan (meninggalkan sisa riba), maka ketahuilah, bahwa Allah dan Rasul-Nya akan memerangimu”. (QS Al Baqarah 279).

Dan Allah berjanji akan memasukkan pelaku riba ke dalam neraka kekal selamanya, Allah berfirman:

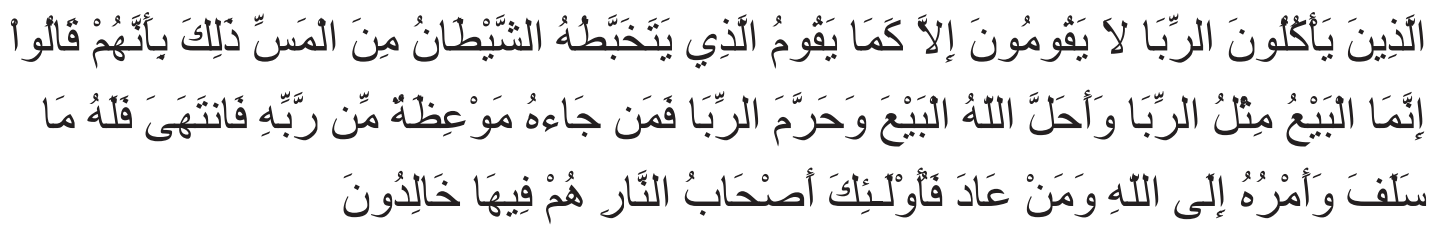

"Orang-orang yang makan (mengambil) riba(1) tidak dapat berdiri melainkan seperti berdirinya orang yang kemasukan syaitan lantaran (tekanan) penyakit gila ${ }^{15}$. Keadaan mereka yang demikian itu, adalah disebabkan mereka berkata (berpendapat), sesungguhnya jual beli itu sama dengan riba, padahal Allah telah menghalalkan jual beli dan mengharamkan riba. Orang-orang yang telah sampai kepadanya larangan dari Tuhannya, lalu terus berhenti (dari mengambil riba), maka baginya apa yang telah diambilnya dahulu(3) (sebelum datang larangan); dan urusannya (terserah) kepada Allah. Orang yang kembali (mengambil riba), maka orang itu adalah penghuni-penghuni neraka; mereka kekal di dalamnya.

Begitu besarnya dosa riba, Rasulullah saw melaknat pelakunya, Sebagaimana diriwayatkan oleh Jabir Ra:

$$
\text { لعن رسو لاله صلّ الله عليه و سلّم اكل الرّبارو مؤكله,ور كاتبه,و شاهديه,ور هم سواء }
$$

"Rasulullah saw mengutuk orang yang makan riba, yang memberikan riba, yang bertransaksi, riba dan kedua saksi transaksi tersebut mereka semuanya berdosa (HR Muslim)

${ }^{15}$ Orang yang memakan riba tidak tentram jiwanya,tafsir ibnu katsir 


\section{Jual-Beli Kredit}

\section{Pengertian dan hukum jual beli kredit}

Jual beli kredit adalah transaksi jual beli dimana barang diterima pada waktu transaksi dengan pembayaran tidak tunai dengan harga yang lebih mahal daripada harga tunai dalam jangka waktu tertentu.

Defenisi jual beli barang secara kredit adalah membeli suatu barang dengan cara berutang, utang tidak dianjurkan dalam syariat Islam kecuali barang tersebut sangat urgen atau diklasifikasikan kebutuhan darurat dan ia merasa tidak mampu untuk melunasinya. Maka tidak dianjurkan seseorang Muslim untuk membeli barang yang merupakan barang mewah secara kredit.

Anas bin Malik ra mengisahkan bahwa Nabi Muhammad saw sering berdoa kepada Allah meminta perlindungan dari lilitan hutang dengan ucapan:

$$
\text { اللهمّ إنّي أعوذبك من الهمّ والحزنوو العجز,و الكسل,و البخل و الجبن,وضلع الدّو غلبة الرّجال }
$$

"Ya Allah sesungguhnya aku berlindung kepada Mu dari keluh kesah dan rasa sedih,dari kelemahan dan kemalasan, dari sifat bakhil dan penakut, dari lilitan utang dan laki-laki yang menindas "(HR. Bukhari).

Ketika beliau ditanya tentang doa tersebut beliau menjawab:

$$
\text { إنّ الرّجال إذا غرم,حدّث فكذب,فأخلف }
$$

"Karena seseorang yang dililit hutang, bila berbicara ia akan berbohong dan bila berjanji ia akan memungkirinya". (HR Bukhari).

Umar bin Khattab berkata "hindarilah berhutang, karena orang yang berhutang mengawali hidupnya dengan kegelisahan dan mengakhirinya dengan kebinasaan" (Atsar ini diriwayatkan Imam Malik dalam kitab Al Muwattha').

Dalil-dalil di atas menunjukkan bahwa berutang tidak dianjurkan dalam Islam kecuali seseorang dalam keadaan sangat membutuhkan. Sebagaimana diriwayatkan oleh Aisyah Ra:

$$
\text { اشترى رسول الله صلّ الله عليه وسلّم من يهودي طعاما بنسيئعة,ورر هنه در عه }
$$

"Rasulullah saw membeli bahan makanan dari seorang Yahudi dengan cara tidak tunai dan memberikan baju besinya sebagai jaminan" (HR. Bukhari).

Dalam hadits di atas di gambarkan bahwa Rasulullah saw berutang untuk kebutuhan pokoknya yaitu mendapatkan bahan makanan untuk diri dan keluarganya, 
bukan untuk sesuatu yang mewah. Ini sangat bertolak belakang dengan perilaku sebagian kaum Muslimin yang berutang untuk membeli barang mewah dengan cara kredit.

Dengan demikian, bila seseorang sangat membutuhkan suatu barang dan diperkirakan ia akan mampu melunasinya, dibolehkan baginya membeli barang dengan cara $\mathrm{kredit}^{16}$. Sekalipun harganya lebih mahal daripada harga tunai bila persyaratan lainnya terpenuhi.

Jual beli kredit dibolehkan dalam Islam sebagaimana hasil keputusan Majma' al Fiqh Islami (divisi OKI) no 51 (2/6)1990, yang berbunyi: "boleh melebihkan harga barang yang dijual dengan tidak tunai daripada dijual tunai. Dan harganya dicicil dalam jangka waktu yang ditentukan",17.

Juga fatwa dewan ulama kerajaan Saudi Arabia No fatwa 1178 yang berbunyi:

"Jual beli kredit hukumnya boleh, dengan syarat bahwa lamanya masa angsuran serta jumlah angsuran diketahui dengan jelas saat akad, sekalipun jual beli kredit biasanya lebih mahal ketimbang jual beli tunai. Hal ini dibolehkan karena keduanya mendapat untung karena harga barangnya lebih mahal dan pembeli mendapat untung karena mendapat tempo tunggakan pembayaran ${ }^{18}$, dan dalil yang mengatakan jual beli kredit dilarang tidak kuat dalilnya"19.

Dalil-dalil yang membolehkan akad ini

1. Al Baqarah 282

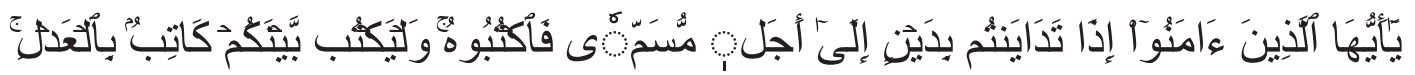

Artinya ; "Hai orang-orang yang beriman, apabila kamu bermu'amalah tidak secara tunai untuk waktu yang ditentukan, hendaklah kamu menuliskannya. Dan hendaklah seorang penulis di antara kamu menuliskannya dengan benar.

\footnotetext{
${ }^{16}$ Dr Sami Sywaylim,Qadhaya fil Iqtishad wat tamwil Islami,hal 37

${ }^{17}$ Journal Islam Fiqh council,vol VII,jilid 2 hal 9

${ }^{18}$ Majmu Fatawa Ibnu Baz jilid XIX hal 105

${ }^{19}$ Journal buhuts Islamiyah edisi VII hal 52
} 
2. Diriwayatkan dari Amru bin Ash ra ia berkata "Nabi menyiapkan unta-unta zakat untuk tunggangan pasukan berjihad, ternyata jumlah unta yang ada tidak mencukupi. Maka Nabi memerintahkanku untuk membeli unta dengan cara tidak tunai dan dibayar nanti bila datang unta zakat. Maka aku beli seekor unta dengan dualtiga ekor unta yang lebih mudah yang dibayar setelah unta zakat datang. tatkala unta zakat datang maka Nabi membayaranya" (HR Ahmad.sanad hadits ini dinyatakan shahih oleh Ar nauth).

Dalam hadits di atas Nabi membenarkan menukar seekor unta yang diterima tunai dengan dua/tiga ekor unta yang dibayarkan nanti setelah unta zakat datang. Ini jelas menunjukkan bahwa boleh menjual barang dengan cara tidak tunai dengan harga lebih mahal daripada tunai ${ }^{20}$.

3. Diriwayatkan bahwa istri Zaid bin Arqam bertanya kepada Aisyah ra tentang jual beli yang dia lakukan.dia menjual budaknya kepada Zaid seharga 800 dirham dibayar tidak tunai, lalu Zaid menjual kembali budak itu kepada istrinya seharga 600 dirham dibayar tunai maka Aisyah Memarahinya.(HR Daruquthni).

Aisyah marah Karena akadnya ini bisa jadi dimaksudkan untuk mengakali riba, karena Zaid menerima 600 dirham tunai, nanti dibayarkan 800 dirham pada waktu akan datang. Ini sama dengan meminjam 600 dirham dan mengganti 800 dirham, maka ini adalah pengakalan riba.

\section{Perbedaan antara riba dan jual beli kredit}

\begin{tabular}{|l|l|}
\hline \multicolumn{1}{|c|}{ Riba } & \multicolumn{1}{c|}{ Jual beli kredit } \\
\hline $\begin{array}{l}\text { Akad pinjam meminjam adalah qardh yang } \\
\text { diharamkan membayarnya dengan nominal } \\
\text { yang lebih besar }\end{array}$ & $\begin{array}{l}\text { Akad jual beli kredit adalah jual beli yang } \\
\text { dibolehkan mengambil keuntungan dari jual } \\
\text { beli hukumnya halal }\end{array}$ \\
\hline $\begin{array}{l}\text { Bunga kredit berasal dari pembiayaan } \\
\text { keuangan, yakni : uang ditukar uang }\end{array}$ & $\begin{array}{l}\text { Laba penjualan kredit berasal dari pembiayaan } \\
\text { barang, yakni : barang ditukar dengan uang }\end{array}$ \\
\hline $\begin{array}{l}\text { Dalam akad riba tidak ada perputaran harta, } \\
\text { hanya uang melahirkan uang }\end{array}$ & $\begin{array}{l}\text { Dalam penjualan kredit terjadi perputaran harta } \\
\text { : dari Uang menjadi barang kemudian kembali } \\
\text { lagi menjadi uang,hal ini membuat roda } \\
\text { ekonomi berputar dan harta tidak dimonopoli } \\
\text { oleh sekelompok kecil orang para pemilik } \\
\text { modal }\end{array}$ \\
\hline
\end{tabular}

${ }^{20}$ Dr Sulaiman At Turki,Ba'I Taqsith wa ahkamuhu,hal 215 
Kredit (riba) merupakan sebab utama terjadinya problem ekonomi yang meresahkan masyarakat dewasa ini dalam bentuk inflasi,karena pertambahan jumlah uang beredar tidak diikuti dengan pertambahan barang dan jasa
Berbeda dengan jual beli kredit,dimana jumlah uang yang dikucurkan diiringi dengan pertambahan barang dan jasa secara riil.

Sebagian ulama kontemporer mengharamkan jual beli kredit yang harganya lebih mahal dari harga tunai, pendapat ini dipopulerkan syaikh Albani Rahimahullah ${ }^{21}$. Diantara dalil yang digunakan adalah hadits Nabi saw yang diriwayatkan oleh Abu Hurairah ra

$$
\text { نهى رسول الله صلّ الله عليه و سلّم عن بيعتين في بيعة }
$$

"Rasulullah saw melarang dua jual beli dalam satu jual beli"

Di antara penafsiran bentuk jual beli dalam satu jual beli, yaitu: saya jual barang ini kredit dengan harga sekian dan tunai dengan harga sekian.

Dalil ini tidak kuat, karena bertentangan dengan dalil-dalil quran dan Sunnah yang telah dijelaskan bahwa yang benarnya adalah, sebagaimana di katakan ibnu Abbas:

$$
\text { لا بأ س أن يقول للسّّعة,هي بنقد بكذا و بنسيئة بكذارو لكن لا يفترقا إلا عن رضا }
$$

"Seseorang boleh menjual barangnya dengan menjual barangnya dengan mengatakan, barang ini tunai harganya sekian dan tidak tunai sekian, akan tetapi tidak boleh penjual dan pembeli berpisah kecuali mereka telah sepakat akan masalah harga"22.

Dan juga sebagaimana dikatakan at Tirmizdi: para ulama menafsirkan makna hadits ini, yaitu melakukan dua jual beli dalam satu jual beli yaitu : penjual berkata,aku jual gamis ini dengan harga 10 dinar tunai dan 20 dinar kredit, lalu penjual dan pembeli berpisah sedangkan kesepakatan atas salah satu jual beli (kredit/tunai) belum terjadi.adapun apabila mereka berpisah dan kesepakatan atas salah satu jual beli telah terjadi maka jual beli ini diperbolehkan. ${ }^{23}$

\footnotetext{
${ }^{21}$ Silsilah ahadits as shahihah,jilid V,hal 426

${ }^{22}$ Mushannaf Ibnu Abi syaibah,jilid V,hal 307

${ }^{23}$ Sunan Tirmizdi jilid III hal 525
} 


\section{Jurnal Asy-Syukriyyah}

\section{Pengetahuan Masyarakat tentang Riba}

Pengetahuan adalah merupakan hasil "tahu" dan ini terjadi setelah orang melakukan pengindraan terhadap suatu objek tertentu ${ }^{24}$. Menurut Taufik ${ }^{25}$, pengetahuan merupakan penginderaan manusia, atau hasil tahu seseorang terhadap objek melalui indera yang dimilikinya (mata, hidung, telinga, dan lain sebagainya). Pengetahuan yang tercakup dalam domain kognitif mempunyai 6 (enam) tingkatan, yaitu :
a. Tahu (know) yang diartikan sebagai mengingat suatu materi yang telah.
b. Memahami (comprehension)
c. Aplikasi (application).
d. Analisis (analysis).
e. Sintesis (synthesis)
f. Evaluasi (evaluation)

Ada beberapa faktor yang mempengaruhi pengetahuan yaitu :

2) Umur,

3) Intelegensi,

4) Lingkungan,

5) Sosial budaya,

6) Pendidikan,

7) Informasi,

8) Pengalaman.

Menurut Arikunto ${ }^{26}$, mengemukakan bahwa untuk mengetahui secara kualitas tingkat pengetahuan yang dimiliki oleh seseorang dapat dibagi menjadi empat tingkat yaitu:

a. Tingkat pengetahuan baik bila skor atau nilai 76-100\%

b. Tingkat pengetahuan cukup bila skor atau nilai 56-75\%

c. Tingkat pengetahuan kurang bila skor atau nilai 40-55 \%

d. Tingkat pengetahuan buruk bila skor atau nilai $<40 \%$

\footnotetext{
${ }^{24}$ Notoatmodjo, Soekidjo (1997). Ilmu Kesehatan Masyarakat. Jakarta : Rineka Cipta

${ }^{25}$ Taufik, M (2007). Prinsip-Prinsip Promosi Kesehatan Dalam Bidang Keperawatan. Jakarta : CV. Infomedika

${ }^{26}$ Arikunto, Suharsimi,1998. Prosedur Penelitian Suatu Pendekatan Praktek, Jakarta Cetakan 8, Rineka Cipta
} 


\section{Jurnal Asy-Syukriyyah}

Pengukuran pengetahuan dapat dilakukan dengan wawancara atau angket yang menanyakan tentang isi materi yang akan diukur dari subjek penelitian atau responden. Kedalaman pengetahuan yang ingin kita ketahui atau kita ukur dapat kita sesuaikan dengan tingkatan-tingkatan di atas.

\section{Daya Beli Masyarakat}

Secara bahasa, daya beli adalah kemampuan masyarakat dalam membelanjakan uangnya dalam bentuk barang maupun jasa atau kemampuan membayar untuk memperoleh barang yang dikehendaki atau diperlukan.

\section{Kerangka Pemikiran Teoritik}

Dari teori yang dibangun pada Bab II menunjukkan bahwa Implementasi kesejahteraan merupakan dasar teoritik untuk menganalisis masalah kemacetan di ibu kota Jakarta. Kebijakan yang dimaksudkan disini adalah Kebijakan dalam bentuk UU No 2 Tahun 1999. Munculnya aturan ini tidak terlepas dari adanya masalah pada lingkungan Jakarta yang mengalami degradasi kemacetan sebagai akibat dari pertumbuhan penduduk yang diikuti dengan besarnya jumlah kendaraan.

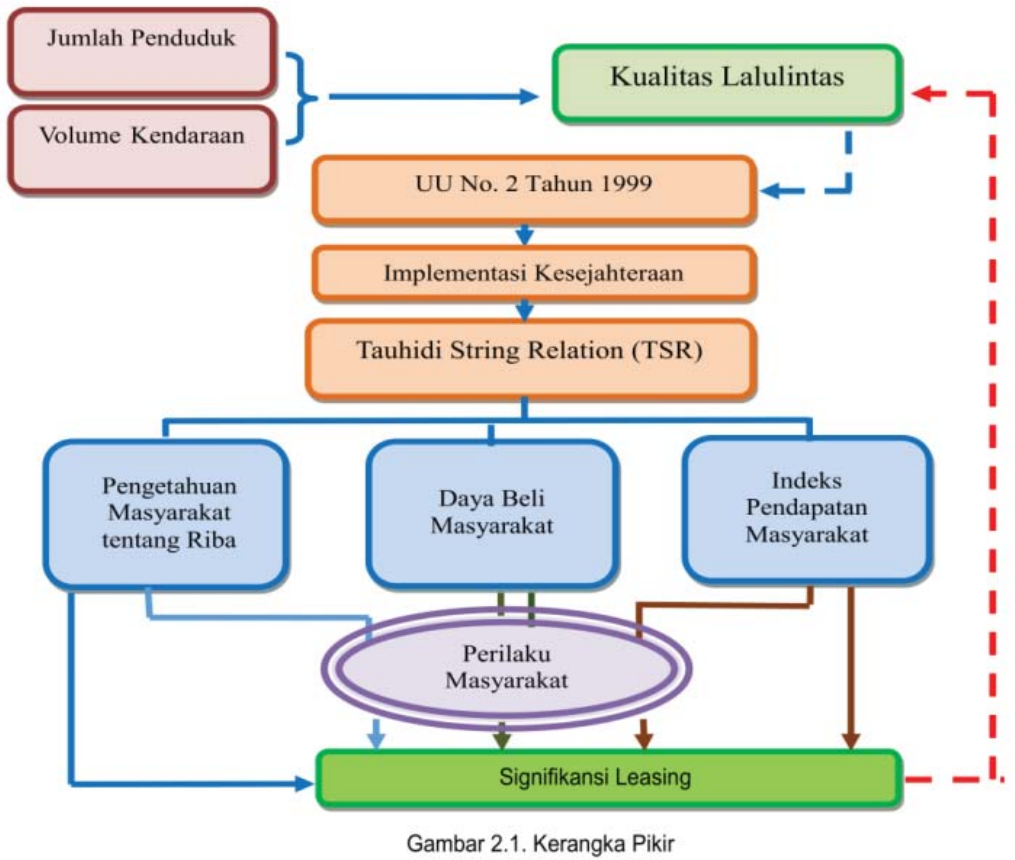




\section{Jurnal Asy-Syukriyyah}

Untuk menganalisis seberapa besar signifikansi Leasing terhadap kemacetan di ibu kota Jakarta digunakan tiga variabel bebas (eksogen) serta satu variabel antara (intervening) yang diambil dari beberapa konsep TSR. Tiga variabel eksogen atau bebas adalah tingkat pengetahuan masyarakat tentang riba, daya beli dan indeks pendapatan masyarakat. Adapun variabel antara (intervening) yaitu perilaku masyarakat. Berdasarkan kajian teoritis dan kerangka pikir serta pemelihan variabel penelitian, maka selanjutnya disusun hipotsis penelitian.

\section{Hasil Penelitian}

a. $\mathrm{H}_{1}$ : Terdapat pengaruh positif yang signifikan tingkat pengetahuan masyarakat tentang riba terhadap kemacetan di ibu kota Jakarta.

$\mathrm{H}_{0}$ : Tidak Terdapat pengaruh positif yang signifikan tingkat pengetahuan masyarakat tentang riba terhadap kemacetan di ibu kota Jakarta.

$\mathrm{H}_{0}: \rho=0$

$\mathrm{H}_{1}: \rho \neq 0$

b. $\mathrm{H}_{1}$ : Terdapat pengaruh yang signifikan daya beli masyarakat terhadap kemacetan di ibu kota Jakarta.

$\mathrm{H}_{0}$ : Tidak terdapat pengaruh yang signifikan daya beli masyarakat terhadap kemacetan di ibu kota Jakarta.

$\mathrm{H}_{0}: \rho=0$

$\mathrm{H}_{1}: \rho \neq 0$

c. $\mathrm{H}_{1}$ : Terdapat pengaruh yang signifikan indeks pendapatan masyarakat terhadap kemacetan di ibu kota Jakarta.

$\mathrm{H}_{0}$ : Tidak Terdapat pengaruh yang signifikan indeks pendapatan masyarakat terhadap kemacetan di ibu kota Jakarta.

$\mathrm{H}_{0}: \rho=0$

$\mathrm{H}_{1}: \rho \neq 0$

d. $\mathrm{H}_{1}$ : Terdapat pengaruh yang signifikan tingkat pengetahuan masyarakat tentang riba terhadap kemacetan melalui perilaku masyarakat.

$\mathrm{H}_{0}$ : Tidak Terdapat pengaruh yang signifikan tingkat pengetahuan masyarakat tentang riba terhadap kemacetan melalui perilaku masyarakat.

$\mathrm{H}_{0}: \rho=0$ 
$\mathrm{H}_{1}: \rho \neq 0$

e. $\mathrm{H}_{1}$ : Terdapat pengaruh yang signifikan daya beli masyarakat terhadap kemacetan di ibu kota Jakarta melalui perilaku masyarakat.

$\mathrm{H}_{0}$ : Tidak Terdapat pengaruh yang signifikan daya beli masyarakat terhadap kemacetan di ibu kota Jakarta melalui perilaku masyarakat.

$\mathrm{H}_{0}: \rho=0$

$\mathrm{H}_{1}: \rho \neq 0$

f. $\mathrm{H}_{1}$ : Terdapat pengaruh yang signifikan indeks pendapatan masyarakat terhadap kemacetan melalui perilaku masyarakat.

2) $\mathrm{H}_{0}$ : Tidak Terdapat pengaruh yang signifikan indeks pendapatan masyarakat terhadap kemacetan melalui perilaku masyarakat.

$\mathrm{H}_{0}: \rho=0$

$\mathrm{H}_{1}: \rho \neq 0$

\section{Kesimpulan}

Data di atas menunjukkan banyaknya institusi ribawi yang digunakan oleh masyarakat di dalam memenuhi pola konsumsi akan kendaraan bermotor, di pengaruhi oleh minimnya pengetahuan masyarakat tentang riba yang mengakibatkan banyaknya masyarakat menggunakan Lembaga pembiayaan ribawi. Terdapat faktor ribawi didalam kemacetan di ibu kota Jakarta, sebgaian besar kendaraan bermotor di beli dengan instrument ribawi. Kemacetan adalah salah satu bentuk adzab Allah swt kepada masyarakat yang tenggelam di dalam praktek riba di ibu kota Jakarta. Dengan kata lain, sistematis praktek ribawi di ibu kota Jakarta berdampak negatif terhadap kemacetan dan juga berimplikasi kepada perekonomian, kesehatan, lingkungan dan psikologis. 


\section{DAFTAR PUSTAKA}

Abdullah Al Umrani,Al Manfa'atu fil qardh, hal 186

Arikunto, Suharsimi,1998. Prosedur Penelitian Suatu Pendekatan Praktek, Jakarta Cetakan 8, Rineka Cipta

http://www.antaranews.com/berita/473169/jumlah-motor-dan-mobil-di-jakarta-tumbuh-12persen-tiap-tahun

http://www.DirektoratPengelolaanPembiayaandanResikoKemenkeu.com

http://www.fifkredit.com/fif/produk-layanan/syariah.php/

Informasi Statistik BPS Jakarta April 2016

Journal Islam Fiqh council,vol VII,jilid 2 hal 9

Journal buhuts Islamiyah edisi VII hal 52

Majmu Fatawa Ibnu Baz jilid XIX hal 105

Muhammad, Rifqi. 2008. Akuntansi Keuangan Syariah. Yogyakarta: P3EI Press

Mushannaf Ibnu Abi syaibah,jilid V,hal 307

Notoatmodjo, Soekidjo (1997). Ilmu Kesehatan Masyarakat. Jakarta : Rineka Cipta

Rafiq Al Mishri,Jami’ Ushulurriba,hal 22

Republika tahun 2015 tanggal 22 mei, Media cetak

Sami Sywaylim,Qadhaya fil Iqtishad wat tamwil Islami,hal 37

Silsilah ahadits as shahihah,jilid V,hal 426

Sunah Tirmizdi jilid III hal 525

Sulaiman At Turki,Ba'I Taqsith wa ahkamuhu,hal 215

Sudarsono Heri. 2008. Bank dan Lembaga Keuangan Syariah. Yogyakarta: Ekonisia.

Taufik, M (2007). Prinsip -Prinsip Promosi Kesehatan Dalam Bidang Keperawatan. Jakarta : CV. Infomedika

Tafsir Ibnu Katsir, Jil. 1, Orang yang memakan riba tidak tentram jiwanya

Yuliadi, Imamudin. 2007. Ekonomi Islam Filosofi, Teori dan Implementasi. Yogyakarta. 